\title{
FLUID ORIGIN AND EVOLUTION DURING THE FORMATION OF RARE-ELEMENT PEGMATITES FROM THE BORBOREMA PROVINCE, NORTHEAST BRAZIL.
}

\section{HARTMUT BEURLEN, MARCELO REIS RODRIGUES DA SILVA AND CLÁUDIO DE CASTRO ${ }^{1}$}

\begin{abstract}
Microthermometric studies of fluid inclusions in the Borborema Pegmatitic Province, Northeast Brazil, allowed to recognize the following fluid types: A) primary aqueous carbonic $\left(17-21 \mathrm{~mol} \% \mathrm{CO}_{2}\right)$ inclusions in early pegmatite minerals, such as garnets and tourmaline (wall zone I) and beryl, quartz, tourmaline and manganotantalite (zone II and limit zone II/III); B) primary aqueous fluid inclusions with low $\mathrm{CO}_{2}$ contents ( $£ 7 \mathrm{~mol} \%$ ), hosted in zoned quartz crystals, apatite and euclase from zone III, core and replacement bodies of the pegmatites; C) late aqueous inclusions barren in $\mathrm{CO}$ in the same minerals than type $\mathrm{B} ; \mathrm{D}$ ) secondary inclusions in all minerals throughout the whole pegmatite, being either aqueous carbonic, showing wide ranges of $\mathrm{CO}_{2} / \mathrm{H}_{2} \mathrm{O}$ ratios (type D1) or aqueous, with no CO (D2). The salinity of these fluids range from low (A and B) to moderate (C) and very low (D). Trapping temperatures decrease from type A to type D inclusions. Laser Raman Microspectrometry analyses of the carbonic phase of the type A inclusions confirmed the absence of methane, but detected significant $\mathrm{N}_{\text {, }}$ contents. The observed $\mathrm{N}_{2} / \mathrm{CO}_{2}$ ratios, ranging between $1 / 5$ and $1 / 70$ are higher than those reported in magmatic fluids associated with pegmatites or granitic magmas $(£ 1 / 140)$. The high $\mathrm{N}_{2} / \mathrm{CO}_{2}$ ratios could be the result of wall rock fluid contamination. High $\mathrm{N}_{2}$ contents in metamorphic fluids are frequently explained by $\mathrm{N}_{2}$ liberation during the mica break down.
\end{abstract}

Keywords: aqueous-carbonic fluid inclusions, Raman data, pegmatites

INTRODUCTION The aim of this paper is to elucidate the fluid evolution during the formation of pegmatites of the Borborema Pegmatitic Province (BPP), in Northeastern Brazil, based on fluid inclusion data. Similar approaches, despite its importance, have never been attempted in the BBP and it is still controversial whether pegmatites form from water saturated (Jahns and Burnham 1969, Burnham and Nekvasil 1986) or undersaturated magmas (London 1986, London et al. 1989)

The BPP approximately overlaps the southern part of the Seridó Foldbelt, between $6^{\circ}$ and $7^{\circ 0}$ of southern latitude and $36^{\circ \circ} 15^{\prime}$ and $36^{\circ}$

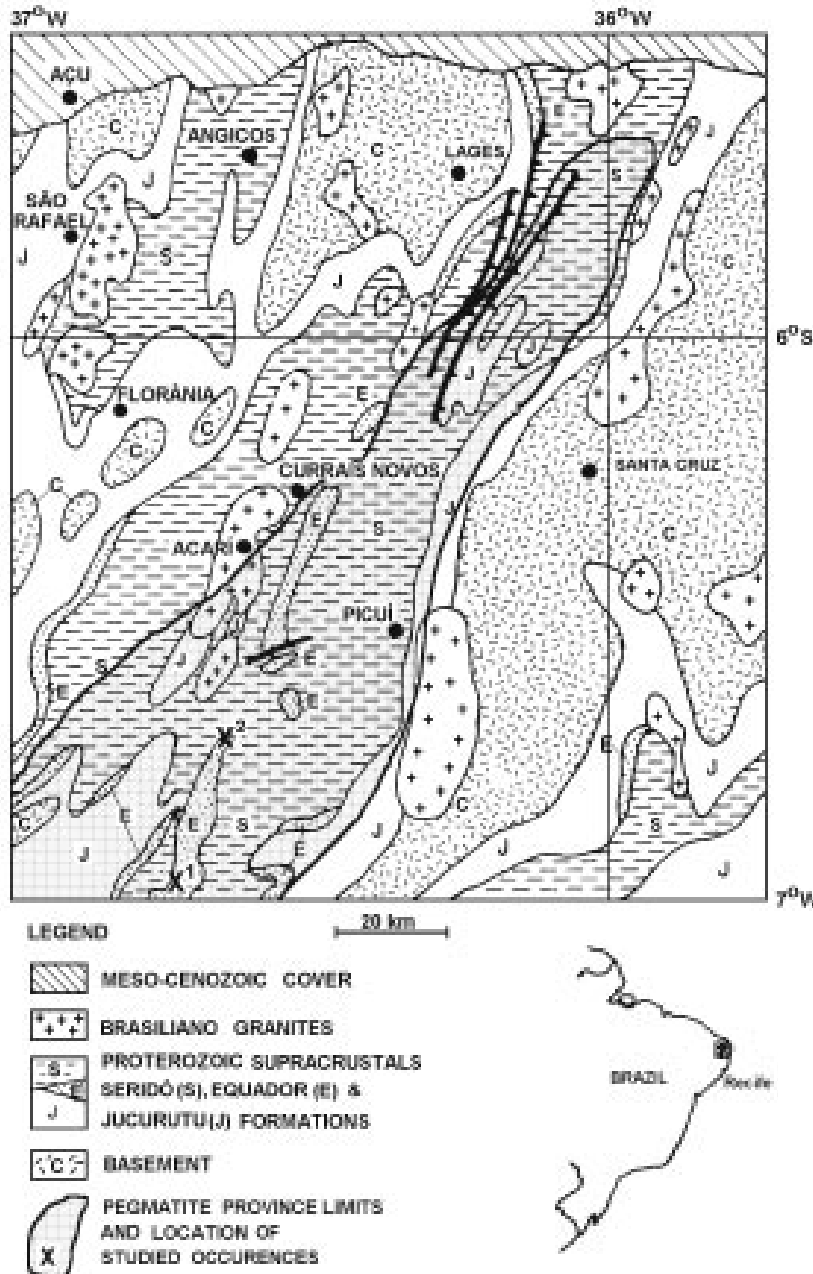

Figure 1 - Simplified geologic map of the Seridó Foldbelt, modified after Jardim de Sá et al. (1981) displaying the extension of the Borborema Pegmatitic Province and the studied pegmatites at Mamões $\left(\mathbf{X}^{\mathbf{1}}\right.$, in the south) and Boqueirão $\left(\mathbf{X}^{\mathbf{2}}\right)$
45' western longitude, in the States of Paraíba and Rio Grande do Norte, in Northeastern Brazil. The Seridó Foldbelt is a Meso- to Neoproterozoic unit of the Borborema Tectonic Province. It is composed of a basal volcanosedimentary sequence (Jucurutu Formation), followed by quartzites and metaconglomerates (Equador Formation) overlain by a turbiditic-flyschoid sequence (Seridó Formation). The sequence underwent upper amphibolite facies metamorphism (Abukuma type) followed by retrograde metamorphism in the upper greenschist facies.

Over $90 \%$ of the pegmatites are found intruded in the schists of the Seridó Formation or the quartzites of the Equador Formation (Fig.1). $\mathrm{U} / \mathrm{Pb}$ and $\mathrm{Rb} / \mathrm{Sr}$ ages of the pegmatites (Ebert 1969 and Almeida et al. 1968) indicated crystallization of the pegmatites between 480 and 510 Ma.

Most of the over 750 mineralized pegmatites of the BPP show a heterogeneous mineral distribution. The pegmatites at Boqueirão, Mamões and Capoeiras, investigated in the present paper, are found intruding quartzites and metaconglomerates of the Equador Formation and are classical examples of this zonation (Fig. 2).
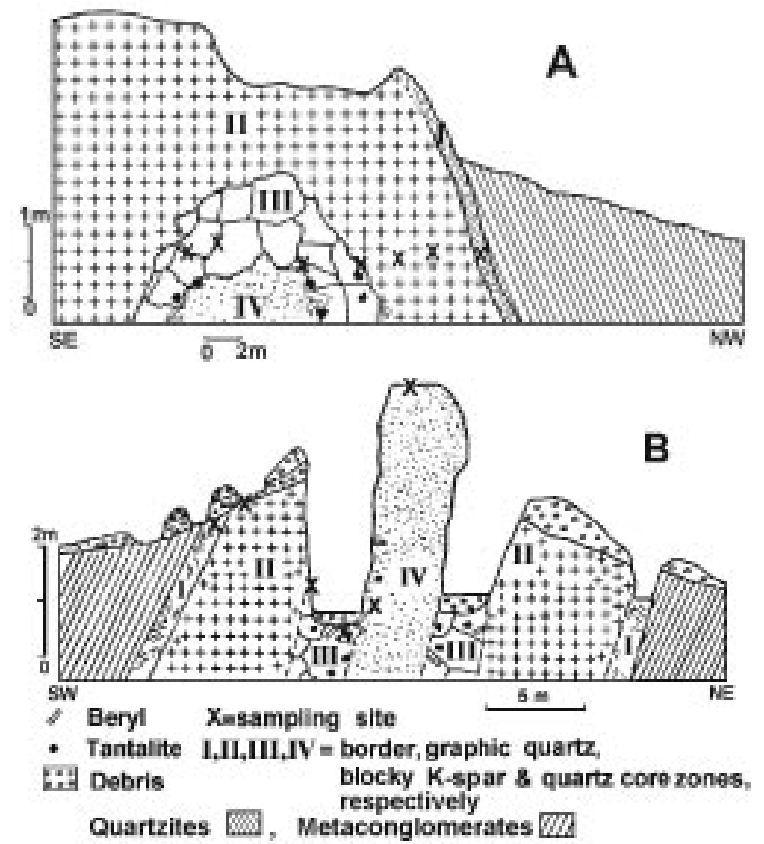

Figure 2 - Schematic cross sections after Da Silva (1993) and sample locations of the Mamões $(A)$ and Boqueirão $(B)$ pegmatites. $I=$ border zone with comb-textured muscovite +albite +quartz; II = medium grained pegmatite with frequent graphic $K$-spar+quartz intergrowths; $I I I=$ blocky $K$-spar (perthite) zone; $I V=$ massive quartz core. The limit between zones III and IV is the preferential site of the so called "replacement bodies" : irregular pockets of medium-grained clevelandite, muscovite, lepidolite, phosphates and disseminated ore minerals.

1 Departamento de Engenharia de Minas, Universidade Federal de Pernambuco, R. Acad. Hélio Ramos sn, 50740-530, Recife, PE, Brazil. E-mail: beurlen @ npd.ufpe.br, marcelor@npd.ufpe.br 
Table 1 - Petrographic and microthermometric data of representative groups of pegmatites from the Borborema Province.

\begin{tabular}{|c|c|c|c|c|c|c|c|}
\hline \multirow{2}{*}{$\begin{array}{c}\text { Host minerals, (zone), } \\
\text { Pegmatite name }\end{array}$} & \multicolumn{3}{|c|}{ Petrographic features } & \multicolumn{4}{|c|}{ Microthermometric data } \\
\hline & nature & $\begin{array}{l}\text { Type/(phases } \\
\text { at room T) }\end{array}$ & vol \% $\mathrm{CO}_{2 \text { (liq) }}$ & $\underset{{ }^{\circ} \mathrm{C}}{\mathrm{Tm} 2}$ & $\begin{array}{c}\text { salinity } \\
\text { wt } \% \mathrm{NaCl} \\
\text { eq }\end{array}$ & ${ }^{\mathrm{T}} \mathrm{C}$ & ${ }^{\text {Thtot }} \mathrm{C}$ \\
\hline $\begin{array}{l}\text { Quartz from graphic pegmatite } \\
\text { (zone II) Boqueirão. }\end{array}$ & $\begin{array}{l}\text { pseudosec+sec } \\
\text { secondary } \\
\text { secondary } \\
\text { secondary }\end{array}$ & $\begin{array}{c}\boldsymbol{A} /(\mathrm{AC} \pm \mathrm{S}) \\
\boldsymbol{D} /(\mathrm{C}) \\
\boldsymbol{C a} /(\mathrm{A} \pm \mathrm{S}) \\
\boldsymbol{C b} /(\mathrm{A} \pm \mathrm{S})\end{array}$ & $\begin{array}{c}70-25 \text { (liq) } \\
100-80 \text { (liq) } \\
0 \\
0\end{array}$ & $\begin{array}{c}56.9 \pm 0.1(92 \\
) \\
56.9 \pm 0.1(31 \\
)\end{array}$ & $\begin{array}{c}4.3 \pm 1.0(96) \\
3.1 \pm 2.3(31) \\
16.7 \pm 2.1(17 \\
) \\
\end{array}$ & $\begin{array}{c}26.9 \pm 3.5(87 \\
) \\
21.7 \pm 5.0(21 \\
)\end{array}$ & $272 \pm 33(42)$ \\
\hline $\begin{array}{l}\text { Tourmaline and garnet(limit } \\
\text { zone I and II) Capoeira. }\end{array}$ & primary & $A /(\mathrm{AC} \pm \mathrm{S})$ & 50(liq) & $\begin{array}{c}57.1 \pm 0.5(22 \\
) \\
\end{array}$ & $4.1 \pm 1.0(6)$ & $28.9 \pm 0.9(8)$ & $293 \pm 15(14)$ \\
\hline $\begin{array}{l}\text { Double-colored tourmaline, } \\
\text { (zone II), Boqueirão }\end{array}$ & $\begin{array}{c}\text { primary } \\
\text { secondary }\end{array}$ & $\begin{array}{c}\boldsymbol{A} /(\mathrm{AC} \pm \mathrm{S}) \\
\boldsymbol{C a} /(\mathrm{A} \pm \mathrm{S})\end{array}$ & $\begin{array}{l}30-20 \text { (liq) } \\
0\end{array}$ & $56.9 \pm 0.1(9)$ & $\begin{array}{l}4.1 \pm 0.5(13) \\
5.1 \pm 1.0(34)\end{array}$ & $\begin{array}{c}24.3 \pm 4.7(14 \\
)\end{array}$ & $\begin{array}{l}224 \pm 23(7) \\
174 \pm 23(13)\end{array}$ \\
\hline $\begin{array}{l}\text { Morganite, (limit zone II and } \\
\text { III) Mamões }\end{array}$ & $\begin{array}{c}\text { primary } \\
\text { secondary }\end{array}$ & $\begin{array}{c}\boldsymbol{A} /(\mathrm{AC} \pm \mathrm{S}) \\
\boldsymbol{C} \boldsymbol{c} /(\mathrm{A} \pm \mathrm{S})\end{array}$ & $\begin{array}{l}50(\text { liq }) \\
0\end{array}$ & $\begin{array}{c}56.7 \pm 0.1(74 \\
)\end{array}$ & $\begin{array}{l}3.2 \pm 0.6(56) \\
3.4 \pm 1.5(12)\end{array}$ & $\begin{array}{c}29.7 \pm 4.1(46 \\
)\end{array}$ & $\begin{array}{l}321 \pm 5(71) \\
141 \pm 23(9)\end{array}$ \\
\hline $\begin{array}{l}\text { Manganotantalite, (Zone III), } \\
\text { Mamões }\end{array}$ & primary & $A /(\mathrm{AC} \pm \mathrm{S})$ & $70-40($ liq) & $\begin{array}{c}56.7 \pm 0.1(11 \\
)\end{array}$ & $1.8 \pm 0.3(11)$ & $29.1 \pm 5.1(8)$ & $291 \pm 5(11)$ \\
\hline $\begin{array}{l}\text { Quartz, crystal(limit Zone III } \\
\text { and IV) } \\
\text { Boqueirão }\end{array}$ & $\begin{array}{l}\text { primary, core } \\
\text { primary,zone1 } \\
\text { primary,zone2 } \\
\text { primary,zone3 } \\
\text { primary, rim }\end{array}$ & $\begin{array}{l}\boldsymbol{B} /(\mathrm{AC} \pm \mathrm{S}) \\
\boldsymbol{C} \boldsymbol{a} /(\mathrm{A} \pm \mathrm{S}) \\
\boldsymbol{C b} /(\mathrm{A} \pm \mathrm{S}) \\
\boldsymbol{C b} /(\mathrm{A} \pm \mathrm{S}) \\
\boldsymbol{C} \boldsymbol{c} /(\mathrm{A} \pm \mathrm{S})\end{array}$ & $\begin{array}{c}30 \text { (vapor) } \\
0 \\
0 \\
0 \\
0\end{array}$ & $?$ & $\begin{array}{c}3.5 \pm 1.1(26) \\
5.3 \pm 0.7(93) \\
14.1 \pm 0.7(98 \\
) \\
10.5 \pm 0.7(21 \\
) \\
3.7 \pm 1.3(26)\end{array}$ & $?$ & $\begin{array}{l}289 \pm 16(21) \\
212 \pm 15(80) \\
183 \pm 14(95) \\
182 \pm 7(21) \\
144 \pm 12(16)\end{array}$ \\
\hline $\begin{array}{l}\text { Quartz crystal (Zone III) } \\
\text { Capoeiras }\end{array}$ & $\begin{array}{l}\text { Primary, core } \\
\text { Pseudos, core } \\
\text { Primary, rim }\end{array}$ & $\begin{array}{c}\boldsymbol{A} /(\mathrm{AC} \pm \mathrm{S}) \\
\boldsymbol{B} /(\mathrm{AC} \pm \mathrm{S}) \\
\boldsymbol{C b} /(\mathrm{A} \pm \mathrm{S})\end{array}$ & $\begin{array}{l}50 \text { (liq) } \\
30 \text { (vapor) } \\
0\end{array}$ & $\begin{array}{c}56.8 \pm 0.1(12 \\
) \\
?\end{array}$ & $\begin{array}{c}3.0 \pm 0.3(19) \\
2.8 \pm 0.2(9) \\
23.1 \pm 3.1(25 \\
) \\
\end{array}$ & $\begin{array}{c}29.7 \pm 0.2(19 \\
) \\
?\end{array}$ & $\begin{array}{l}295 \pm 4(19) \\
221 \pm 13(8) \\
213 \pm 13(23)\end{array}$ \\
\hline $\begin{array}{l}\text { Quartz crystal with euclase } \\
\text { overgrowth } \\
\text { (Zone IV or replacement body) } \\
\text { Mamões }\end{array}$ & $\begin{array}{l}\text { Primary,core } \\
\text { Primary,zone2 } \\
\text { Primary,zone3 } \\
\text { Secondary,rim }\end{array}$ & $\begin{array}{l}\boldsymbol{B} /(\mathrm{AC} \pm \mathrm{S}) \\
\boldsymbol{C b} /(\mathrm{A} \pm \mathrm{S}) \\
\boldsymbol{C b} /(\mathrm{A} \pm \mathrm{S}) \\
\boldsymbol{C} \boldsymbol{c} /(\mathrm{A} \pm \mathrm{S})\end{array}$ & $\begin{array}{c}30 \text { (vapor) } \\
0 \\
0 \\
0\end{array}$ & & $\begin{array}{c}6.5 \pm 1.3(15) \\
19.2 \pm 1.0(22 \\
) \\
12.6 \pm 1.7(18 \\
) \\
1.2 \pm 0.1(4) \\
\end{array}$ & & $\begin{array}{c}195 \pm 9(14) \\
178 \pm 19(15) \\
171 \pm 17(14) \\
147 \pm 9(4)\end{array}$ \\
\hline $\begin{array}{l}\text { Aquamarine (zone III) } \\
\text { Papagaio Pegmatite }\end{array}$ & $\begin{array}{l}\text { primary } \\
\text { secondary }\end{array}$ & $\begin{array}{c}\boldsymbol{A} /(\mathrm{AC} \pm \mathrm{S}) \\
\boldsymbol{C b} /(\mathrm{A} \pm \mathrm{S})\end{array}$ & $\begin{array}{c}50 \text { (liq) } \\
0\end{array}$ & $\begin{array}{c}57.1 \pm 0.1(28 \\
)\end{array}$ & $\begin{array}{l}4.1 \pm 0.3(25) \\
8.5 \pm 0.7(14)\end{array}$ & $\begin{array}{c}26.3 \pm 0.5(26 \\
)\end{array}$ & $\begin{array}{l}297 \pm 15(23) \\
221 \pm 27(15)\end{array}$ \\
\hline $\begin{array}{l}\text { Apatite from replacement } \\
\text { body, Alto Feio }\end{array}$ & primary & $\boldsymbol{B} /(\mathrm{AC} \pm \mathrm{S})$ & 30 (vapor) & $56.6 \pm 0.3(5)$ & $0.4 \pm 0.3(15)$ & & $249 \pm 23(13)$ \\
\hline $\begin{array}{l}\text { Graphic pegmatite } \\
\text { all samples, } \\
\text { Mamões, Ubaieiras, } \\
\text { and Capoeira pegmatites }\end{array}$ & $\begin{array}{l}\text { pseudosec } \\
\text { secondary } \\
\text { secondary } \\
\text { secondary } \\
\text { secondary }\end{array}$ & $\begin{array}{c}\boldsymbol{A} /(\mathrm{AC} \pm \mathrm{S}) \\
\boldsymbol{C} \boldsymbol{a} /(\mathrm{A} \pm \mathrm{S}) \\
\boldsymbol{C b} /(\mathrm{A} \pm \mathrm{S}) \\
\boldsymbol{C} \boldsymbol{c} /(\mathrm{A} \pm \mathrm{S}) \\
D /(\mathrm{AC}) \\
\end{array}$ & $\begin{array}{c}25-75 \\
0 \\
0 \\
0 \\
100-0 \\
\end{array}$ & $\begin{array}{r}56.6-57.1 \\
56.6-57.9 \\
\end{array}$ & $\begin{array}{c}3,0-7,0(65) \\
3.0--5.5(42) \\
10-25(58) \\
0-4(25)\end{array}$ & $\begin{array}{l}21-30(55) \\
10-31(31) \\
\end{array}$ & $\begin{array}{l}260-340(62) \\
240-300(44) \\
170-220(95) \\
110-200(20) \\
100-400(24)\end{array}$ \\
\hline
\end{tabular}

Obs.: $\mathrm{A}=$ aqueous, $\mathrm{C}=$ carbonic; $\mathrm{AC}=$ aqueous-carbonic; $\pm \mathrm{S}=$ with accidentally trapped solids, mainly muscovite;

pseudosec. =pseudosecondary; The numbers in parenthesis represent the number of measurements. Types $\boldsymbol{A}, \boldsymbol{B}, \boldsymbol{C a}, \boldsymbol{C b}, \boldsymbol{C c}$ and $\boldsymbol{D}$ as explained in the text.

\section{FLUID INCLUSION MICROTHERMOMETRY}

PETROGRAPHY

AND

The investigated pegmatites were sampled systematically along cross sections from the walls to the core of the pegmatites, passing through the graphic zone and the blocky feldspar zone to the massive quartz core (Fig. 2). In addition, a second set of samples, consisting of perfectly idiomorphic crystals, mostly collected in open vugs was also investigated. The petrographic characteristics and the microthermometric data are discussed in detail by Beurlen et al. (2000) The most important features are summarized in Table 1 and Figs. 4 and 5. The following types of fluid inclusions were distinguished:

-type A are primary aqueous-carbonic inclusions (liquid $\mathrm{CO}_{2} / \mathrm{H}_{2} \mathrm{O}$ ratios close to 1.0) with accidentally trapped solids ( $\mathrm{Lw}+\mathrm{Lc}+\mathrm{V} \pm \mathrm{S}$ ), in garnet, tourmaline, beryl (Figs. 3A, 3B), manganotantalite and in the cores of some quartz crystals. Fluid inclusions with the same phase ratios are frequently found in quartz grains from zones I and II, in planar pseudosecondary arrays, and sometimes in tridimensional clusters or isolated inclusions.

-type $\mathrm{B}$ are $\mathrm{Lw}+\mathrm{V} \pm \mathrm{S}$ inclusions with low $\mathrm{CO}_{2}$ contents in the vapor phase, only detected by clathration during microthermometric runs. They appear as primary inclusions in the core or surrounding Type A- bearing cores in quartz crystals, within secondary trails crosscutting type A arrays in graphic quartz and in growth zones of apatite from replacement bodies.

-type $\mathrm{C}$ are primary aqueous $(\mathrm{Lw}+\mathrm{V} \pm \mathrm{S})$ inclusions with accidentally trapped solids (Figs. 3C and D) but, devoid of $\mathrm{CO}_{2}$ They occur surrounding type A or type B inclusions in successive crystal growth zones of some quartz crystals (Fig. 3E and F). They also occur along secondary trails in graphic quartz, tourmaline, beryl and quartz crystals from zones II and III. Sub-types $\mathrm{Ca}, \mathrm{Cb}$ and $\mathrm{Cc}$ could be distinguished on the basis of decreasing homogenization temperatures and, respectivelly, low, moderate and very low salinities obtained during microthermometric observations.

-type D are secondary aqueous (sub-type D1) and aqueous-carbonic (sub-type D2) inclusions with very irregular shape and size found in late intragranular or transgranular trails in quartz of all the pegmatite zones. The $\mathrm{CO}_{2} / \mathrm{H}_{2} \mathrm{O}$ ratios in inclusions of the D2 sub-type, in contrast with the constant ratios within type A inclusions, are very variable within single trails.

The final $\mathrm{CO}_{2}$ melting temperatures shown in Fig.4, range between -56.4 and $-57.4{ }^{2} \mathrm{C}$ in all the primary aqueous-carbonic inclusions and indicate the predominance of $\mathrm{CO}_{2}$ and the absence of large amounts of other volatiles. 

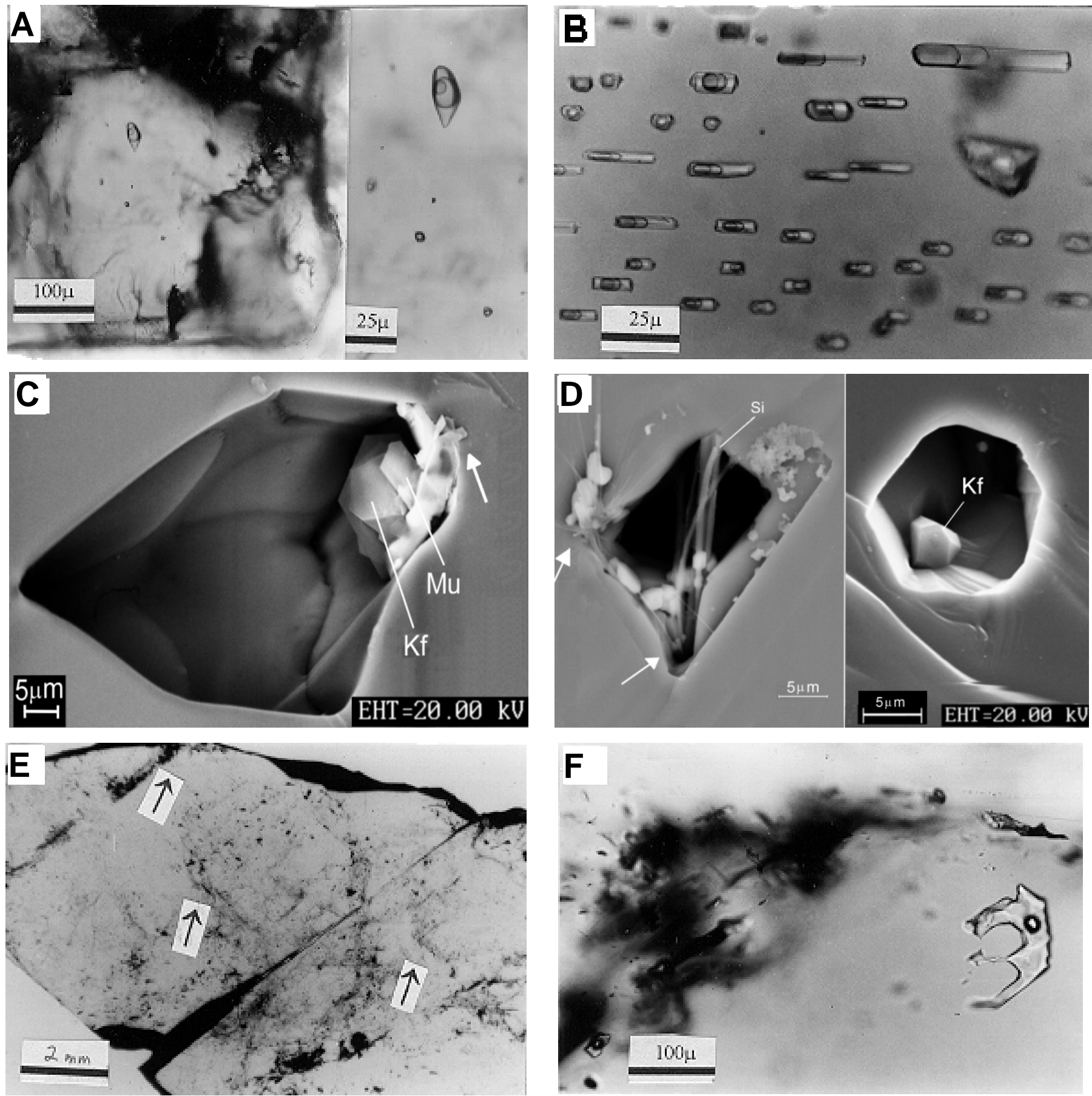

Figure 3 - A) Primary, type A, $\mathrm{H}_{2} \mathrm{O}-\mathrm{CO}_{2}$ inclusions in an idiomorphic tourmaline grain included in feldspar from zone II of the Capoeiras Pegmatite. The $\mathrm{H}_{2} \mathrm{O} /$ $\mathrm{CO}_{2}$ ratio around 1.0 is shown in the magnification in the right side. B) Ttype A, aqueous-carbonic inclusions, oriented parallel to the C axis of the host morganite crystal, from the limit between zones II and III of the Mamoes Pegmatite. Observe the constancy of the water/CO ratios of the long prismatic aqueouscarbonic inclusions. The estimated liquid $\mathrm{H}_{2} \mathrm{O} / \mathrm{CO}_{2}$ volume ratios at $32^{\circ} \mathrm{C}$ range between 1.1 and 0.9 . Accidentally trapped solids are also observed in some fluid inclusions. C and D) SEM images of primary inclusions with accidentally trapped $K$-spar (Kf), muscovite (Mu) and a fibrous silicate (Si), probably of Li and/or Be. Note that the solids are partially enclosed in the wall quartz of the fluid inclusion (arrows). E) Prismatic section of a quartz crystal from the limit zone III/zone IV of the Boqueirão Pegmatite showing primary inclusion arrays (arrows) along successive pyramidal growth zones. F) Detail of a large primary, type $\mathrm{Cb}$, negative crystal shaped, aqueous inclusion, from the last pyramidal inclusion array of Fig. $3 G$ (arrow in the left).

Even though most samples present an incomplete sequence of these fluid inclusion types, an outstanding common feature is that the homogenization temperature, always decreases from type A (range of mean $\mathrm{Th}$ values from 290 to $\left.330^{\circ} \mathrm{C}\right)$ to type $\mathrm{Cc}\left(140\right.$ to $\left.180^{\circ} \mathrm{C}\right)$ inclusions (Table 1, Fig. 5A to 5C). These microthermometric results are in full agreement with the relative age and the mostly primary nature of the fluid inclusion types established petrographically. This becomes particularly proeminent in Fig. $5 \mathrm{~A}$ where type $\mathrm{B}, \mathrm{Ca}, \mathrm{Cb}$ and $\mathrm{Cc}$ inclusions occur in successive crystal growth zones of a single quartz crystal from Boqueirão (Fig. 3E and F). Another feature common to most samples is the low salinity during the formation of type $\mathrm{A}, \mathrm{B}$ and $\mathrm{Ca}$ inclusions ( $£ 8 \mathrm{wt} \% \mathrm{NaCl}$ eq.) increasing to moderate values in type $\mathrm{Cb}$ ( 10 to $25 \mathrm{wt} \% \mathrm{NaCl}$ eq. ), followed by a new decrease in type $\mathrm{Cc}(£ 6 \mathrm{wt} \% \mathrm{NaCl}$ eq.) inclusions (Figs.5A, B, C). Type $\mathrm{D}$ inclusions were not included in Fig. 5 because of the large variations in $\mathrm{H}_{2} \mathrm{O} / \mathrm{CO}_{2}$ ratios and homogenization temperatures, and because they only occur in secondary trails.

The first ice melting temperatures also present a significant change from $\mathrm{Ca}$ (between -20 and $-30^{\circ} \mathrm{C}$ ) to $\mathrm{Cb}$ type inclusions $\left(-35\right.$ to $\left.-55^{\circ} \mathrm{C}\right)$ returning to normal values $\left(-20\right.$ to $\left.-25^{\circ} \mathrm{C}\right)$ in type $\mathrm{Cc}$ inclusions. 


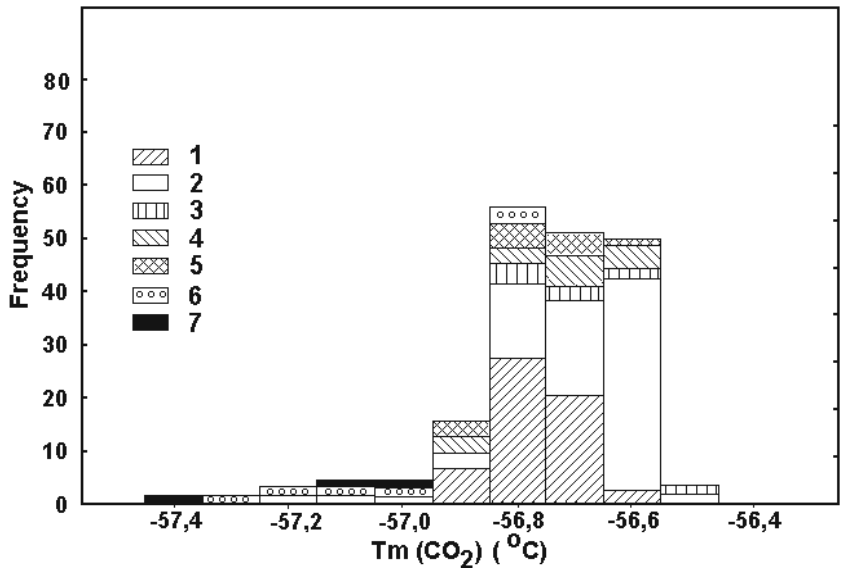

Figure 4 - Histogram of final $\mathrm{CO}_{2}$ melting temperatures [Tm $\left(\mathrm{CO}_{2}\right)$ ] in Type $A$ aqueous-carbonic inclusions in some representative samples: graphic quartz (1), tourmaline (5), of the Boqueirão, quartz crystal (4), garnet (6) and tourmaline (7) of the Capoeiras and morganite, (2) and manganotantalite (3) of the Mamões Pegmatite.

LASER RAMAN MICROSPECTROMETRY (LRM) LRM analyses of the carbonic phase of 46 selected fluid inclusions were obtained. No signals other than $\mathrm{CO}_{2}$ and/or $\mathrm{N}_{2}$ were observed in the inclusions with exception of two inclusions which presented $\mathrm{CH}_{4}$ contents below $0.2 \mathrm{~mol} \%$. These data are in perfect agreement with the measured $\mathrm{CO}_{2}$ and clathrate melting temperatures which indicated the predominance of $\mathrm{CO}_{2}$ in the carbonic phase. $\mathrm{N}_{2}$ signals were observed in 23 inclusions, with very variable $\mathrm{CO} / \mathrm{N}_{2}$ ratios. All examined large ( $>20 \mathrm{~mm})$ type $\mathrm{A}\left(\mathrm{Lw}+\mathrm{Lc} \pm \mathrm{S}\right.$ at temperatures $\left.>32^{\circ} \mathrm{C}\right)$ inclusions in tourmaline and in quartz crystals presented $\mathrm{N}_{2}$ signals with $\mathrm{CO} / \mathrm{N}_{2}$ ratios between 18 and 70. In graphic quartz only 6 of 14 examined type A inclusions presented $\mathrm{N}_{2}$ signals, possibly due to the smaller size (5 to $15 \mathrm{~mm}$ ) of these inclusions and the smaller diameter of the carbonic phase close to the detection limit. In four large type A inclusions in morganite no $\mathrm{N}_{2}$ signals were observed.

In five type $\mathrm{B}$ and one type $\mathrm{Ca}$ inclusions in the zoned quartz crystal, in which the presence of a carbonic $(\mathrm{V})$ phase was suspected because of clathration phenomena during microthermometric runs, the Raman results were able to detect good $\mathrm{CO}_{2}$ signals and, in five of these cases, also the presence of $\mathrm{N}_{2}$. The molar $\mathrm{CO}_{2} / \mathrm{N}_{2}$ ratios ranged between 4 and 9 .

Because of the large variation of the $\mathrm{CO}_{2} / \mathrm{N}_{2}$ ratios, most of the results must be considered as a preliminary, semi-quantitative, approach with respect to the $\mathrm{N}_{2}$ contents and $\mathrm{CO} / \mathrm{N}_{2}$ ratios Nevertheless, if only the data in which $\mathrm{CO}_{2}$ peak areas surpassed $100 \mathrm{cps}$ and the $\mathrm{N}_{2}$ peaks (if detected) were larger than 2 times the largest air signal observed during the whole period of measurements are considered ( data listed in Table 2), the ratios still show a large range between 5 and 70. It is outstanding that these ratios are much lower - e.g. the $\mathrm{N}_{2}$ contents much higher - than the usual ratios found in magmatic fluids of acid volcanic rocks (mean of 180, ranging from 150 to 250) and in the also supposedly magmatic fluids of the Tanco pegmatite (Manitoba, Canada, mean of 180, range from 93 to 275) as reported by Thomas and Spooner (1992). The almost complete absence of $\mathrm{CH}_{4}$ in the investigated pegmatites is also in contrast with the data of the Tanco pegmatite, where the $\mathrm{CH}_{4}$ contents of the carbonic phase are always similar to those of $\mathrm{N}_{2}$.

DISCUSSION The relative age between fluid inclusion types and the stages of pegmatite crystallization was established based on petrographic and microthermometric data obtained mainly from the Boqueirão, Mamões and Capoeiras pegmatites. Type A aqueouscarbonic fluids found in garnet and tourmaline crystals from zones I and II at Capoeiras and in morganite, aquamarine, manganotantalite, quartz crystals and graphic quartz from zones II and III at Boqueirão and Mamões are the earliest identified fluids. They are supposed to have coexisted with the pegmatitic magma already during the onset of the zone II crystallization. At the end of the zone III crystallization the presence of aqueous type B fluids is documented by primary inclusions
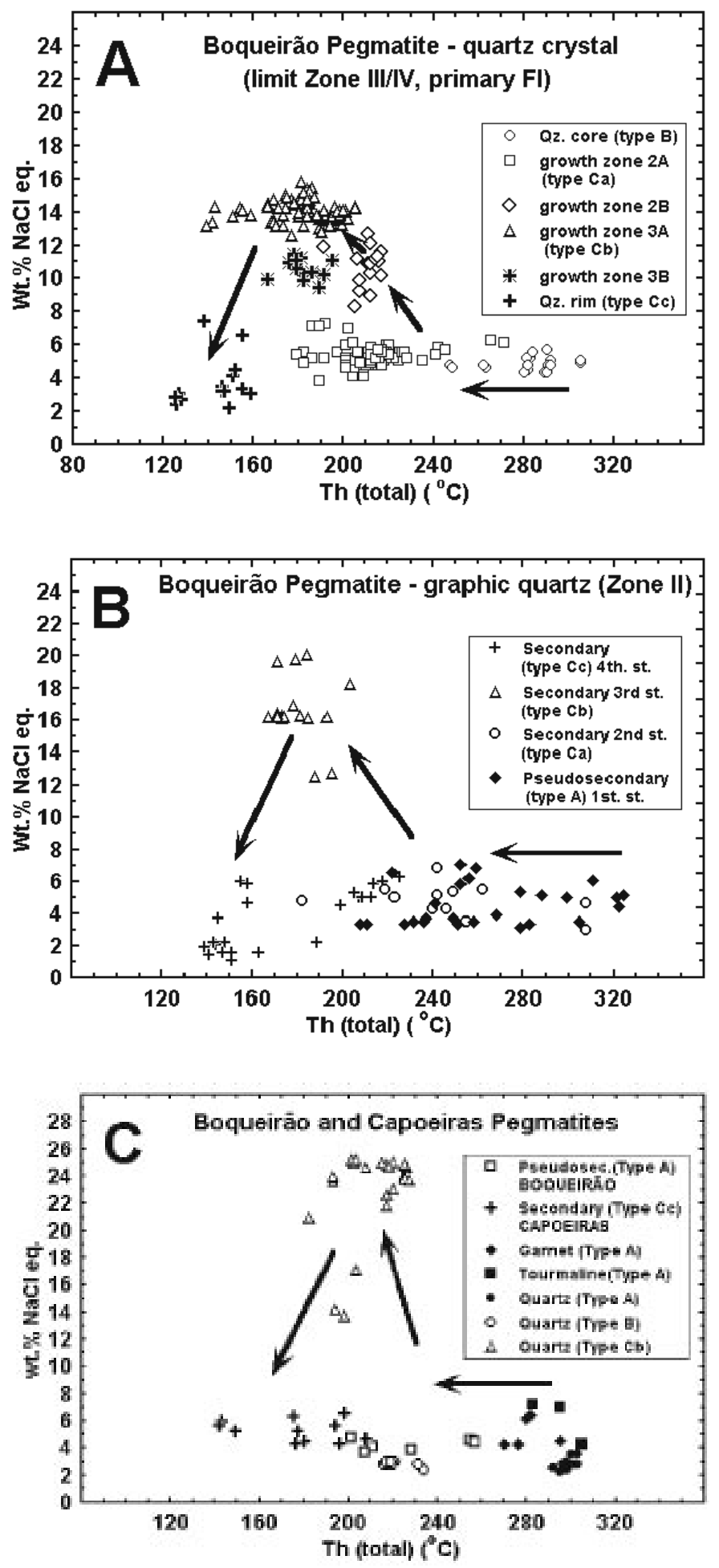

Figure 5 - Selected salinity (in wt. \% NaCl eq.) versus total homogenization temperature $\left[\right.$ Th $\left.(\text { total })^{\circ} \mathrm{C}\right]$ diagrams. The salinities were calculated using FLINCOR software (Brown 1989), from final ice melting temperatures in aqueous inclusions and from final clathrate melting temperatures in aqueouscarbonic inclusions. A) in successive crystal growth zones in a quartz crystal from the limit between zone III and IV, at Boqueirão. B) in graphic quartz at Boqueirão. $C$ ) in tourmaline from zone II of the Boqueirão Pegmatite, and garnet and tourmaline from zone II and a quartz crystal from zone III of the Capoeiras pegmatite. The arrows indicate the relative age of different inclusion populations as indicated by crosscutting relations in secondary trails $(B)$ or by the relative position of primary inclusions in successive crystal growth zones ( $A$ and $C$ ). The arrows also indicate the most probable fluid evolution during the crystallization of the pegmatites. 
Table 2 - Raman data and bulk inclusion parameters of selected individual fluid inclusions calculated according to Ramboz et al. (1985).

\begin{tabular}{|c|c|c|c|c|c|c|c|c|c|c|c|c|c|c|c|c|}
\hline \multicolumn{5}{|c|}{ PETROGRAPHIC FEATURES } & & & \multirow{2}{*}{\multicolumn{3}{|c|}{$\frac{\text { RAMAN DATA }}{(\text { mole } \%)}$}} & \multicolumn{2}{|r|}{ BULK } & \multicolumn{2}{|c|}{ INCLUSION } & \multicolumn{3}{|c|}{ PARAMETERS } \\
\hline & & & & & & & & & & \multicolumn{5}{|c|}{$($ mole $\%)$} & \multirow{2}{*}{$\begin{array}{l}\mathrm{d}_{\text {(bulk) }} \\
\mathrm{g} / \mathrm{cc} \\
\end{array}$} & \multirow{2}{*}{$\begin{array}{l}\mathrm{CO}_{2} / \\
\chi \mathrm{N}_{2} \\
\end{array}$} \\
\hline Number & $\begin{array}{c}\text { Typ } \\
\text { e }\end{array}$ & Host mineral & $\begin{array}{l}\text { Pegmati- } \\
\text { te zone }\end{array}$ & $\mathrm{V} \% \mathrm{Aq}$ & $\begin{array}{l}\mathrm{Daq} \\
\mathrm{g} / \mathrm{cc}\end{array}$ & $\begin{array}{c}\mathrm{dCO}_{2} \\
\mathrm{~g} / \mathrm{cc}\end{array}$ & $\mathrm{ZCO}_{2}$ & $\mathrm{ZN}_{2}$ & $\overline{\mathrm{ZCH}_{4}}$ & $\chi \mathrm{H}_{2} \mathrm{O}$ & $\chi \mathrm{NaCl}$ & $\chi \mathrm{CO}_{2}$ & $\chi \mathrm{N}_{2}$ & $\chi \mathrm{CH}_{4}$ & & \\
\hline BO1-1-69 & $\mathrm{B}$ & Quartz & III & 70 & 1.018 & 0.240 & 83.0 & 17.0 & - & 92.4 & 1.05 & 5.8 & 0.72 & - & 0.785 & 8.1 \\
\hline BO1-1-72b & $\mathrm{B}$ & Quartz & III & 70 & 1.074 & 0.240 & 75.0 & 25.0 & - & 89.7 & 3.72 & 5.5 & 1.09 & - & 0.824 & 5.1 \\
\hline BO3-1-10 & A & Quartz & II & 65 & 1.017 & 0.631 & 97.2 & 02.8 & - & 84.9 & 0.57 & 14.2 & 0.34 & - & 0.882 & 41.7 \\
\hline BO3-1-2 & $\mathrm{A}$ & Quartz & II & 65 & 1.017 & 0.631 & 94.4 & 05.6 & - & 84.8 & 0.57 & 14.0 & 0.69 & - & 0.882 & 20.3 \\
\hline MA1-13 & $\mathrm{A}$ & Morganite & II/III & 50 & 1.014 & 0.608 & 100.0 & - & - & 77.5 & 0.64 & 21.8 & - & - & 0.811 & - \\
\hline MA1-37 & $\mathrm{A}$ & Morganite & II/III & 50 & 1.014 & 0.608 & 99.3 & - & 0.75 & 77.5 & 0.64 & 21.7 & - & 0.15 & 0.811 & - \\
\hline CA1-b-72 & $\mathrm{A}$ & Tourmaline & /III & 50 & 1.024 & 0.654 & 94.3 & 05.7 & - & 75.9 & 0.78 & 22.1 & 1.22 & - & 0.839 & 18.1 \\
\hline CA6-1-d-1 & $\mathrm{A}$ & Tourmaline & II & 60 & 1.020 & 0.302 & 92.5 & 06.8 & 0.73 & 88.5 & 1.34 & 9.6 & 0.52 & 0.11 & 0.733 & 18.4 \\
\hline CA1-B-1 & $\mathrm{A}$ & Tourmaline & I/II & 50 & 1.021 & 0.615 & 95.7 & 04.3 & - & 76.9 & 0.82 & 21.4 & 0.86 & - & 0.818 & 24.9 \\
\hline CA11-1-2 & $\mathrm{A}$ & \begin{tabular}{|l|} 
Quartz \\
\end{tabular} & III & 50 & 1.020 & 0.604 & 98.4 & 01.6 & - & 77.4 & 0.80 & 21.5 & 0.31 & - & 0.812 & 68.8 \\
\hline CA11-1-6 & $\mathrm{A}$ & Quartz & III & 50 & 1.012 & 0.600 & 98.2 & 01.8 & - & 77.7 & 0.58 & 21.4 & 0.36 & - & 0.806 & 59.7 \\
\hline CA11-1-7 & $\mathrm{A}$ & Quartz & III & 50 & 1.010 & 0.628 & 98.4 & 01.6 & - & 77.1 & 0.50 & 22.1 & 0.32 & - & 0.819 & 69.9 \\
\hline
\end{tabular}

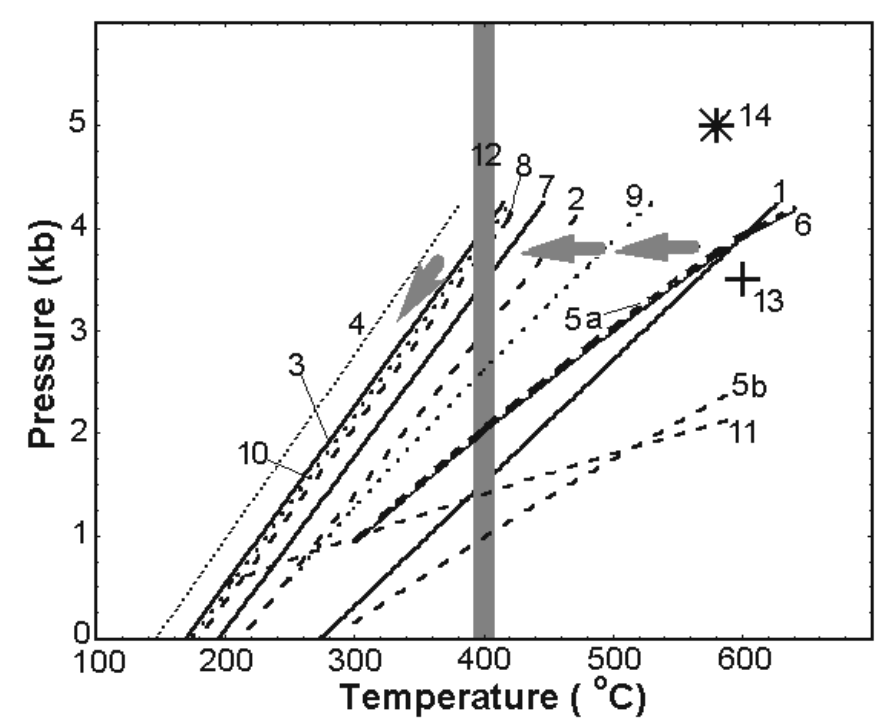

Figure 6 - P-T diagram showing the isochores for the most representative fluid inclusion types in minerals from different zones of the Boqueirão and Mamões Pegmatites in the Borborema Pegmatitic Province. Isochores 1 to 4 represent primary aqueous inclusions of the core $(1=$ type $B)$ and successive growth zones (2, 3 and 4, respectively types $C a, C b$ and $C c)$ in a quartz crystal from the limit between zones III and IV of the Boqueirão Pegmatite. Lines 5 a and 5 b correspond to primary aqueous-carbonic inclusions (Type A) in morganite and 6 in manganotantalite of the transition between zones II and III of the Mamões Pegmatite. Isochores 7 and 8 represent inclusions of the core and rim (+euclase) of a quartz crystal from zone $I V$ (respectively types $C a$ and $C b$ ). Isochores 9 (type A), 10 (type $\mathrm{Ca}$ ) and 11 (type $\mathrm{Cb}$ ) stand for successive stages of secondary inclusion trails in graphic quartz (zone II) of the Boqueirão Pegmatite. The vertical shadowed bar (12) represents the maximum stability conditions of euclase in equilibrium with quartz. (Barton 1986). Points 13 and 14 represent estimates of regional metamorphic conditions of the Serido schists. The arrows indicate the most probable P/T evolution path for fluids in equilibrium with the pegmatite during its crystallization from zone II to zone IV: isobaric cooling from 580 to $400^{\circ} \mathrm{C}$ at $3.5 \mathrm{~kb}$.

in the core of the quartz crystal from Boqueirão and in apatite from Capoeiras. The inclusions in the successive growth zones of the same quartz crystal from Boqueirão (and also from Capoeiras) support the evolution to $\mathrm{CO}_{2}$-free aqueous fluids (types $\mathrm{Ca}, \mathrm{Cb}$ and $\mathrm{Cc}$ ). The $\mathrm{Cb}$ type inclusions in euclase, apatite rims and quartz growth zones rich in muscovite, probably represent the main fluid during the formation of the replacement bodies.

It can be easily observed in Fig. 6 that the isochores 5a, 6 and 1 (respectively type A and type B inclusions) crosscut each other at $580^{\circ}$
$\mathrm{C}$ and $3.5 \mathrm{~kb}$. These conditions are considered to be close to the trapping conditions because of the following reasons:

Type A fluid was followed by type B during the pegmatite crystallization. Thus large trapping pressure differences between them are unlikely.

These values are close to estimates of the regional metamorphism of the Seridó Group (points 13 and 14 in Fig. 6, according to Gama Jr. and Albuquerque 1985 and Lima 1986, respectively).

The presence of large idiomorphic spodumene crystals formed at the limits between zones III and IV of the Boqueirão and Capoeiras pegmatites, instead of petalite, imposes a minimum trapping pressure between 2.5 and $3.5 \mathrm{~kb}$ (respectively at 400 and $600^{\circ} \mathrm{C}$, London et al. 1989).

The pressure of $3.5 \mathrm{~kb}$ is also indicated by isochores 3 and 8 (Fig. 6), corresponding to primary type $\mathrm{Cb}$ inclusions in the quartz crystal intergrown with euclase, at the maximum stability temperature of euclase $\left(380\right.$ to $\left.420^{\circ} \mathrm{C}\right)$ in the presence of quartz (Barton 1986).

These values $\left(580^{\circ} \mathrm{C} / 3.5 \mathrm{~kb}\right)$ agree with the emplacement conditions of rare-element pegmatites admitted by Èerný (1992) and to the pegmatite liquidus established by London et al. (1989) .

Therefore, the most plausible interpretation is to suppose that the crystallization of the major part of the studied pegmatites (zone II and part of zone III) occurred at $3.5 \mathrm{~kb}$, first in the presence of type A and later in the presence of type B fluids. During this stage slow cooling conditions (or, less probably, fast crystallization rates) should have prevailed. A faster cooling, from $\pm 580^{\circ} \mathrm{C}$ to $\pm 400^{\circ} \mathrm{C}$, occurred during the formation of the inner part of zone III, the quartz core and the replacement bodies, still under nearly isobaric conditions, as indicated by the isochores $1,2,3$ and 4 , corresponding to primary inclusions in successive growth zones in the same quartz crystal.

The composition of the fluids evolved from a low salinity ( $<8 \mathrm{wt} \%$ $\mathrm{NaCl}$ eq. ) aqueous-carbonic (14 to $23 \mathrm{~mol} \% \mathrm{CO}_{2}$ ) type A fluid, to a low salinity aqueous type B fluid with $\mathrm{CO}_{2}$ contents less than $5 \mathrm{~mol} \%$. These fluids are followed by $\mathrm{CO}_{2}$-free aqueous fluids with salinitiy evolving from low (type $\mathrm{Ca}$ ) to moderate (type $\mathrm{Cb}$, around $10 \mathrm{~mol} \%$ $\mathrm{NaCl}$ eq., contemporaneous to the formation of replacement bodies) and again to very low values (type $\mathrm{Cc}$ ). Later type $\mathrm{D}$ inclusions are only found in secondary trails and are of dubious position in the fluid evolution history.

The evolution from $\mathrm{CO}_{2}\left(+\mathrm{N}_{2}\right)$-rich to $\mathrm{CO}_{2}$-poor, and later to aqueous fluids could be explained by an early influx of metamorphic aqueous-carbonic fluids (in agreement with $\mathrm{CO}_{2} / \mathrm{N}_{2}$ ratios below 70) into a nearly $\mathrm{H}_{2} \mathrm{O}$ saturated pegmatitic magma.

Acknowledgements To CNPq (Grants 523401/94 and 520053/ 96), Roberto P. Xavier and Dailto da Silva (FI Laboratory, UNICAMP, São Paulo) for the invaluable help with the Raman and SEM analyses and to two referees of RBG for the critical review of the manuscript. 


\section{References}

Almeida F.F.M., Melcher G.C., Cordani U.G., Kawashita K., Vandoros P. 1968 Radiometric age determinations from Northern Brazil. São Paulo, Soc. Bras. Geol. /SBG, p. 3-15(Boletim 17).

Barton M. 1986. Phase equilibria and thermodinamic properties of minerals in the BeO$\mathrm{Al}_{2} \mathrm{O}_{3}-\mathrm{SiO}_{2}-\mathrm{H}_{2} \mathrm{O}$ (BASH) system with petrologic applications. Amer. Mineral.,

Beurlen H., Da Silva M.R.R., Castro C. 2000. Fluid inclusion microthermometry in Be-Ta(Li-Sn) bearing pegmatites from the Borborema Province, Northeast Brazil. Chem. Geol. In print

Brown P. E. 1989. FLINCOR: a computer program for the reduction and investigation of fluid inclusion data. Amer. Mineral., 74: 1390 - 1393.

Burnham C.W., Nekvasil, H. 1986. Equilibrium properties of granite pegmatite magmas Amer. Mineral., 71: 239-236.

Èerný P. 1992. Rare element granitic pegmatites. Part 1: anatomy and internal evolution of pegmatite deposits. Geosc. Can., 18: 49-67.

Da Silva M.R.R. 1993. Petrogtraphical and geochemical investigation of pegmatites in the Borborema Pegmatitic Province of Northeast Brazil. Ludwig-Maximilian Universität München, Dr. Rer. Nat. Dissertation, $305 \mathrm{p}$.

Ebert H. 1969. Geologia do Alto Seridó. Recife, SUDENE, Serie Geol. Reg., 120 p. (Boletim 11)

Gama T. Jr., Albuquerque C.A.R. 1985. Petrologia do Grupo Seridó, Currais Novos - Parelhas (RN). Rev. Bras. Geociências, 15: 131-138.

Jahns R.H. \& Burnham W. 1969. Experimental studies of pegmatite genesis- I. a model for the derivation and crystallization of granitic pegmatites. Econ. Geol., 64:843-864.
Jardim de Sá E.F., Legrand J.M., McReath I. 1981. Estratigrafia de rochas granitóides na Região do Seridó (RN-PB) com base em critérios estruturais. Rev. Bras. Geociências, 11:50-57.

Lima E.S. 1986. Metamorphism and tectonic evolution in the Seridó Region, Northeastern Brazil. Dept. Earth \& Space Scxi.,Univ. of California Los Angeles, Ph.D. Thesis, $215 \mathrm{p}$.

London D. 1986. Magmatic-hydrothermal transition in Tanco Pegmatite. American Mineralogist, 71: 376-395.

London D., Morgan G.B.V., Hervig R.L. 1989. Vapor undersaturated experiments in the system macusanite - $\mathrm{H}_{2} \mathrm{O}$ at $200 \mathrm{Mpa}$ and the internal differentiation of granitic pegmatites. Contrib. Mineral. and Petrology, 102:1-17.

Ramboz C., Schnapper D., Dubessy J. 1985. The P-V-T-X-fO evolution of $\mathrm{H}_{2} \mathrm{O}-\mathrm{CO}_{2}-\mathrm{CH}$ bearing fluids in a wolframite vein: reconstruction from fluid inclusion studies. Geoch. Cosmochim. Acta, 49:205-219.

Thomas A.V. \& Spooner E.T.C. 1992. The volatile geochemistry of magmatic $\mathrm{H} 2 \mathrm{O}-\mathrm{CO}$ fluid inclusions from the Tanco zoned granitic pegmatite, southeastern Manitoba, Canada. Geoch. Cosmochim. Acta, 56:49-66.

Contribution IGC-055 Received February 3, 2000 Acepted for publication May 16, 2000 